\title{
Regulation of intestinal immune responses through TLR activation: implications for pro- and prebiotics
}

\author{
Sander de Kivit ${ }^{1}{ }^{*}$, Mary C. Tobin ${ }^{2}$, Christopher B. Forsyth ${ }^{1}$, Ali Keshavarzian ${ }^{1,3}$ and Alan L. Landay ${ }^{2,3}$ \\ 1 Division of Digestive Diseases and Nutrition, Rush University Medical Center, Chicago, IL, USA \\ ${ }^{2}$ Department of Immunology/Microbiology, Rush University Medical Center, Chicago, IL, USA \\ ${ }^{3}$ Division of Pharmacology, Utrecht Institute for Pharmaceutical Sciences, Faculty of Science, Utrecht University, Utrecht, Netherlands
}

\section{Edited by:}

Christophe M. Filippi, Genomics

Institute of the Novartis Research

Foundation, USA

Reviewed by:

Ari Waisman, University Medical Center of Johannes Gutenberg

University Mainz, Germany

Muriel Moser, Université Libre de

Bruxelles, Belgium

*Correspondence:

Sander de Kivit, Division of Digestive Diseases and Nutrition, Rush

University Medical Center, 1735 West Harrison Street, Chicago, IL 60612

USA

e-mail: sander_dekivit@rush.edu
The intestinal mucosa is constantly facing a high load of antigens including bacterial antigens derived from the microbiota and food. Despite this, the immune cells present in the gastrointestinal tract do not initiate a pro-inflammatory immune response. Toll-like receptors (TLRs) are pattern recognition receptors expressed by various cells in the gastrointestinal tract, including intestinal epithelial cells (IEC) and resident immune cells in the lamina propria. Many diseases, including chronic intestinal inflammation (e.g., inflammatory bowel disease), irritable bowel syndrome (IBS), allergic gastroenteritis (e.g., eosinophilic gastroenteritis and allergic (BS), and infections are nowadays associated with a deregulated microbiota. The microbiota may directly interact with TLR. In addition, differences in intestinal TLR expression in health and disease may suggest that TLRs play an essential role in disease pathogenesis and may be novel targets for therapy. TLR signaling in the gut is involved in either maintaining intestinal homeostasis or the induction of an inflammatory response. This mini review provides an overview of the current knowledge regarding the contribution of intestinal epithelial TLR signaling in both tolerance induction or promoting intestinal inflammation, with a focus on food allergy. We will also highlight a potential role of the microbiota in regulating gut immune responses, especially through TLR activation.

Keywords: toll-like receptors, intestinal epithelial cells, food allergy, microbiota, probiotics, prebiotics, circadian rhythm

\section{THE MUCOSAL IMMUNE RESPONSE IN THE INTESTINE - AN OVERVIEW}

The mucosal tissue of the intestines contains the largest part of the immune system present in the human body, and is constantly exposed to many antigens, which are derived from amongst others food and micro-organisms including the commensal microbiota or invading pathogens. Approximately, $70 \%$ of the cells of the immune system are present in the gut and are continuously discriminating between harmless and pathogenic antigens. Nevertheless, the majority of oral foreign antigens do not result in inflammatory responses in healthy individuals. This phenomenon is known as oral tolerance. Local or systemic pathological inflammation may occur when oral tolerance toward some harmless luminal antigens is lost. This is seen for instance in food allergy, which is characterized by an inflammatory immune response toward generally harmless food-derived antigens.

Intestinal epithelial cells (IEC) provide a physical and chemical barrier between the intestinal lumen and the lamina propria. The expression of tight junction proteins by IEC, production of mucus by goblet cells and Paneth cell-derived antimicrobial peptides prevent translocation of luminal antigens and micro-organisms into the lamina propria $(1,2)$. Nevertheless, antigens are actively sampled into the gut-associated lymphoid tissue (GALT). Understanding of the GALT is essential to gain insight in both disease pathogenesis and to design new therapeutic strategies to prevent or cure inflammatory diseases of the intestine. As an antigen ends up in the lumen of the intestine, it is generally recognized by dendritic cells (DC) present in Peyer's patches, after the antigen has been transported into the Peyer's patch via specialized IEC known as M cells $(3,4)$. Antigen sampling also occurs via dendrites of DC that protrude between the IEC $(5,6)$. Upon antigen recognition, DC migrate toward the draining mesenteric lymph nodes (MLN) and activate $\mathrm{T}$ cells, which migrate back toward the intestinal lamina propria to carry out their effector functions (7).

Intestinal epithelial cells have been described to suppress DC activation as well and contribute to tolerance induction by secreting amongst others TSLP and TGF- $\beta$, and metabolize vitamin A into retinoic acid to induce the development of $\mathrm{CD}_{103}{ }^{+} \mathrm{DC}(8-$ 12). These $\mathrm{CD}_{103^{+}} \mathrm{DC}$ induce antigen-specific regulatory T cells $\left(\mathrm{T}_{\text {reg }}\right)$ as well as the expression of the specific gut-homing molecules $\alpha 4 \beta 7$ integrin and CCR9 on T cells in the MLN (13). $T_{\text {reg }}$ cells suppress adaptive immune responses through cell-cell contact dependent mechanisms or secretion of the anti-inflammatory cytokines IL-10 or TGF- $\beta$. Indeed, induction of $\mathrm{T}_{\text {reg }}$ cells results in abrogation of food hypersensitivity responses $(14,15)$. A higher frequency of allergen-specific $\mathrm{T}_{\text {reg }}$ cells is observed in children that have outgrown cow's milk allergy and allergen-specific immunotherapy has been shown to induce $\mathrm{T}_{\text {reg }}$ cells $(16,17)$, implicating that the induction of $\mathrm{T}_{\text {reg }}$ cells is essential for mucosal tolerance. 


\section{REGULATION OF INTESTINAL IMMUNITY AND TOLERANCE} BY TLRS EXPRESSED BY IEC

Toll-like receptors (TLRs) recognize a wide range of microbial fragments and therefore recognize both antigens derived from the microbiota as well as invading pathogens. TLRs are expressed by a variety of cells, including IEC. TLR2 can dimerize with TLR1 or TLR6 to recognize bacterial cell wall lipoproteins. LPS produced by Gram-negative bacteria is recognized by TLR4 in conjunction with CD14 and MD2, whereas unmethylated CpG motifs of bacterial DNA are recognized by TLR9. In addition, flagellin is recognized by TLR5, which is expressed at the basolateral membrane by IEC. TLR2, 4 , and 5 are generally expressed at the cell membrane, whereas TLR9 is expressed intracellularly. However, in IEC, TLR9 has been reported to be expressed at the cell membrane as well $(18,19)$.

Under homeostatic conditions, IEC show low expression of TLR2 and TLR4 and are therefore unresponsive to TLR stimuli $(20,21)$. However, under inflammatory conditions, epithelial TLR expression is increased, which contributes to both inflammation as well as immune tolerance $(19,22,23)$. Increased epithelial TLR2 and TLR4 expression is associated with inflammatory bowel disease (24). In contrast, apical TLR9 stimulation has been described to contribute to intestinal homeostasis (18). Interestingly, TLR activation of IEC appears to be important in regulating adaptive immune responses. Using an in vitro co-culture system, it was shown that TLR4 and basolateral TLR9 activation on IEC is important in driving an inflammatory response, whereas apical TLR9 activation supported the differentiation of an anti-inflammatory response (25). The underlying mechanisms by which TLR9 promotes tolerance are not well understood, but it has been described that apical but not basolateral TLR9 ligation on IEC prevents

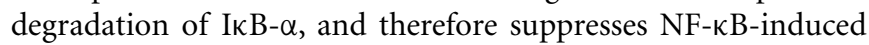
pro-inflammatory cytokine production by IEC (18). In addition, it has recently been indicated that apical TLR9 activation supports the expression and secretion of galectin-9, a soluble protein of the lectin family, which supports the differentiation of $\mathrm{T}_{\text {reg }}$ cells potentially by supporting the development of tolerogenic DC $(26,27)$. Though IEC are important in driving the development of tolerogenic $\mathrm{CD} 103^{+}$DC and suppress DC activation (8), it is not known whether TLR activation on IEC influences the generation of $\mathrm{CD}_{103}{ }^{+} \mathrm{DC}$. Recently, it has been shown that gut bacteria stimulate the recruitment of $\mathrm{CD}_{103}{ }^{+} \mathrm{DC}$ into the epithelium potentially via TLR-dependent mechanisms in both IEC and hematopoietic cells (28). Altogether, TLR stimulation in the intestinal epithelium plays an important role in regulating mucosal immune responses in the intestine.

In addition to regulating intestinal immunity, TLR activation on IEC is also known to modulate the expression of tight junction proteins. In many inflammatory disorders, including food allergy, epithelial tight junctions are impaired and increased bacterial translocation occurs (29). This increased bacterial translocation into the lamina propria may sustain the inflammatory response. In particular, epithelial TLR2 activation has been described to protect against barrier disruption by enhancing zonula occludens (ZO)-1 expression in IEC in a protein kinase C-dependent manner (30). In contrast, activation of TLR4 increases intestinal permeability and results in enhances bacterial translocation (31). NF- $\mathrm{KB}$ signaling as a result of TLR4 activation by LPS appears to play a major role in LPS-mediated barrier disruption $(32,33)$. Similarly, apical Campylobacter jejuni infection of T84 cell monolayers results in a rapid decrease in the transepithelial resistance of the monolayer involving NF- $\kappa B$ signaling (34). Activation of TLR9 apically on IEC prevents TLR4-induced gut leakiness and infection of IEC monolayers with Campylobacter jejuni disrupts the intestinal epithelial barrier function by reducing TLR9 expression at the surface membrane of IEC (33). In this similar study, the authors also indicate an increase in the intestinal barrier function upon apical, but not basolateral TLR9 stimulation with a synthetic CpG DNA (35). Preliminary data from our group also report a potential protective effect of apical TLR9 activation in T84 cell monolayers co-cultured with CD3/28-activated PBMC. Hence, paracellular transport of antigens as well as bacterial translocation under pathological conditions may be affected by TLR activation on IEC.

With respect to food and environmental allergens, the contribution of TLR activation on IEC is not well studied. Recently, TLR4 activation by wheat $\alpha$-amylase trypsin inhibitors, a recognized plant-derived allergen (36), has been described to drive intestinal inflammation (37). The percentage of $\alpha$-amylase trypsin inhibitors is markedly higher in genetically modified grain seeds that are more resistant to infection than traditional seeds (38-40), which might explain why a wheat-free diet could be beneficial in a wide range of inflammatory and allergic disorders. Similarly, the house dust mite allergen Der p 2 as well as the major cat allergen Fel d 1 enhance signaling through TLR2 and TLR4 (41). Although these studies were carried out on innate immune cells, this does not exclude that these allergens may interact with TLR expressed by IEC as well. Especially, since TLR activation on IEC affects the mucosal barrier function and potentially shapes mucosal immune responses in the intestine, interactions of allergens with TLR expressed by IEC may facilitate their entry into the gut mucosa and sustain the allergic inflammatory response. Interestingly, treatment with $\mathrm{CpG}$ oligodeoxynucleotides improved the intestinal barrier function and increased the percentage of $\mathrm{T}_{\text {reg }}$ cells in the spleen and MLN (42). Since epithelial TLR may interact with the gut microbiota and luminal antigens, further understanding of the role of epithelial TLR activation in food allergy is necessary.

\section{INTERACTIONS BETWEEN THE MICROBIOTA AND TLRS}

The microbiota is the largest source of microbial stimulation in the gut. Furthermore, the microbiota is necessary for development of the intestinal immune system (43). The "hygiene hypothesis," currently the most popular theory of deregulation of the microbiota, theorizes that specific microbial stimulation is necessary for gut health. Originally, it states that microbial stimulation polarizes the immune response toward $T_{h} 1$, while lack of microbial stimulation maintains a $T_{h} 2$ polarized immune response, which is characteristic for atopy (44). Recently, a specific microbiota signature was linked to oral allergic sensitization in mice exhibiting a gain-offunction mutation in the IL-4 receptor $\alpha$ chain, which rendered these animals more prone to developing food allergy. This microbiota signature was characterized by a reduction in Firmicutes spp. and increase in Proteobacteria spp. (45). Another example that 
indicates the importance of the gut microbiota composition in the development of food allergy is a recent study showing that colonization of germ-free mice with the fecal microbiota of a healthy infant rich in Bifidobacterium spp. and Bacteroides spp. protected against the development of cow's milk allergy following sensitization to $\beta$-lactoglobulin (46). This was associated with lower $\mathrm{T}$ cell reactivity toward the allergen, an increase in Foxp $3^{+} \mathrm{T}_{\text {reg }}$ and lower bacterial translocation into the lamina propria. Bifidobacterium breve potentially activates $\mathrm{CD} 103^{+}$intestinal DC to produce IL-10 and IL-27 in a TLR2-dependent fashion to induce IL-10-producing $\mathrm{T}_{\mathrm{r}} 1$ cells (47), whereas colonization of germ-free mice with Bacteroides fragilis restores the $\mathrm{T}_{\mathrm{h}} 1 / \mathrm{T}_{\mathrm{h}} 2$ balance and prevents intestinal inflammation through induction of IL-10 producing $\mathrm{CD}^{+} \mathrm{T}$ cells. This was dependent on recognition of $B$. fragilis polysaccharide A by gut DC $(48,49)$.

Disturbances in the commensal bacterial composition in the gut, reflected by increased colonization with Escherichia coli or Clostridium difficile, is associated with an increased risk in the development of allergic disease and IBD in humans $(50,51)$. The fecal microbiota of allergic infants shows a higher prevalence of Clostridium spp. and Staphylococcus aureus. In parallel, lower levels of Bifidobacteria, Enterococci, and Bacteroides were found in the stool of allergic infants compared to healthy individuals (52, 53). Bacterial colonization early in life has been shown to affect cytokine production by $\mathrm{T}$ helper cell subsets, implicating that dysbiosis at an early age may increase the risk of developing food allergy (54). Likewise, infants that have developed eczema by the age of 12 months show a lower diversity in the gut microbiota during the early postnatal period (55). Thus, it appears that low abundance of Bifidobacteria, Enterococci, and Bacteroides and a higher abundance of Clostridium spp. and Staphylococcus are associated with loss of tolerance and an exaggerated allergic response toward food-derived antigens. However, it was recently shown that Clostridium butyricum can induce IL-10 producing macrophages in the gut in a TLR2-dependent manner and suppresses TLR4 expression by colonic IEC $(56,57)$. Hence, host-microbiome interactions not only promote a normal $\mathrm{T}_{\mathrm{h}} 1 / \mathrm{T}_{\mathrm{h}} 2$ balance, but support the development of $\mathrm{T}_{\text {reg }}$ responses as well. Whether changes in microbiota composition are a factor to promote an allergic response to food or are a consequence of food allergy remains to be studied.

It is important to note that not only changes in the microbiota are present in individuals with food allergy, but the response of immune cells toward the microbiota has also been described to be different. The so-called beneficial bacteria are not necessarily associated with anti-inflammatory responses in allergic patients. For example, although an increased prevalence of Bifidobacteria is rendered as beneficial, specific Bifidobacterium strains isolated from the feces of allergic infants were shown to induce increased production of the pro-inflammatory cytokines IL- $1 \beta$, IL-6, and TNF- $\alpha$ (58). This is supported by the observation that the allergic infants showed an increased IL- 6 and TNF- $\alpha$ response toward TLR2, TLR4, and TLR5 stimuli (59).

Using in vitro models it was shown that IEC play an important role in discrimination between different bacterial strains at the apical membrane $(60,61)$. In addition, commensal bacteria have the capacity to enhance TLR expression by IEC (62-66).
This suggests that TLR responses toward microflora constituents may be important. However, not all bacterial strains are equally effective in suppressing food allergy. This is reflected by the selective capacity of bacterial strains to induce Foxp $3^{+} \mathrm{T}_{\text {reg }}$ cells in a murine model for OVA-induced asthma and OVA-induced food hypersensitivity (67). Similarly, only specific Lactobacillus strains attenuate $\mathrm{T}_{\mathrm{h}} 2$ responses by inducing $\mathrm{CD}_{103}{ }^{+}$tolerogenic DC (68). Both Lactobacillus and Bifidobacterium strains have been shown to induce $\mathrm{T}_{\text {reg }}$ type immune responses, thereby suppressing allergy $(47,69-72)$. Recently, it has been shown that the bacterial DNA from Lactobacillus spp. or probiotics contain a higher frequency of immunoregulatory CpG motifs - potentially stimulating TLR9 - when compared to pathogenic bacteria like E. coli, which is important for $\mathrm{T}_{\text {reg }}$ conversion in the intestinal mucosa (73). Exposure of IEC to DNA derived from E. coli or S. dublin induces high IL-8 production by IEC $(19,74)$, whereas DNA from Lactobacillus rhamnosus GG prevents NF-кB-induced IL-8 production by IEC (66). Similarly, apical exposure of IEC to genomic DNA from B. breve M-16V was found to enhance IFN- $\gamma$ and IL-10 secretion by PBMC in an HT-29/PBMC co-culture model (26). In line with this study, it was shown that DC cultured in the conditioned medium of IEC apically exposed to $S$. Dublin DNA, but not from $B$. breve, produced increased amounts of pro-inflammatory cytokines (75). This suggests that not all probiotic bacterial strains are potentially effective in treating allergic diseases. Selection of probiotic bacterial strains should possibly be based on their richness in CpG motifs, targeting TLR9, and bacterial strains high in these motifs may be considered for clinical trials.

\section{PREBIOTICS SHAPE THE INTESTINAL MICROBIOTA}

Breast feeding also affects the microbiota composition by increasing the amount of Bifidobacteria as shown by higher fecal Bifidobacteria counts (76). Human milk contains a high amount of non-digestible oligosaccharides with over 1000 different oligosaccharide structures and it has been shown that human milk, as well as specific dietary fibers like chicory-derived inulin and lactosederived short-chain galacto-oligosaccharides (scGOS), selectively support the growth of Lactobacillus and Bifidobacterium strains (77). Therefore, these oligosaccharides have prebiotic effects in the intestine. Based on the basic structure and size of neutral non-digestible oligosaccharides present in human milk, a specific prebiotic mixture consisting of scGOS and long-chain fructooligosaccharides (lcFOS) in a 9:1 ratio has been developed. Oral supplementation of scGOS/lcFOS has been shown to reduce allergic symptoms in mice and humans (78-80). Especially dietary supplementation with a combination of scGOS/lcFOS and B. breve $\mathrm{M}-16 \mathrm{~V}(\mathrm{GF} / \mathrm{Bb})$ is effective in reducing allergic symptoms (81, 82 ). In a colitis model in rats, inulin, and FOS reduced colitis, which was associated with increased Bifidobacterium species and reduced Enterobacteriaceae and C. difficile in the feces (83). The underlying mechanisms are not known. However, exposure of IEC to $\mathrm{GF} / \mathrm{B} b$ may result in the generation of tolerogenic DC and consequently $\mathrm{T}_{\text {reg }}$ polarization in the GALT. In addition to supporting $\mathrm{T}_{\text {reg }}$ conversion, stimulation of the growth of Lactobacillus and Bifidobacterium strains may also improve the intestinal barrier function in a TLR2 and potentially TLR9 dependent manner $(84,85)$. 


\section{CIRCADIAN CLOCK AND TLR}

Although the type of microbiota composition is a critical factor for the state of TLR activation in the gut of patients with allergic disorders, other environmental factors can also influence TLR activation. It has recently been shown that the expression of TLRs is under regulation of the circadian clock. This implicates that the expression of TLRs is not temporally fixed in a $24-\mathrm{h}$ day and night cycle. Recently, the expression of TLR9 as well as other TLRs were shown to be regulated by the circadian clock $(86,87)$. Interestingly, the severity of TLR9-mediated induction of sepsis is associated with the time-dependent expression of TLR9 (86). Moreover, further studies have indicated that the interaction between the microbiota and TLRs expressed by the gut epithelium is dependent on the circadian rhythm as well (88). Besides the observation that the expression of TLRs is under circadian control, cytokine production by macrophages and $\mathrm{CD} 4^{+} \mathrm{T}$ cells, the suppressor function of Foxp $3^{+} \mathrm{T}_{\text {reg }}$ cells, leukocyte trafficking, and antibody production also show a circadian pattern (89-97). Furthermore, it was recently shown that the circadian clock is critical for regulation of intestinal permeability as well, as disruption of the circadian rhythm led to increased microbial translocation and disruption of the epithelial tight junctions (98). Hence, interactions between the microbiota and the intestinal mucosal immune system may not only be dependent on the type of bacterial species present in the microbiome, but are also temporally regulated, which may contribute to regulation of immune responses in the intestine. These data may explain why many allergic reactions like asthma attacks occur in the early morning $(99,100)$. Recently, it was shown that the expression of the Fc£RI by mast cells and IgE-mediated mast cell degranulation is temporally regulated by the circadian clock $(101,102)$. Also, it might, at least partially, explain the rapid rise of incidence of (food) allergies in western societies where disruption of normal circadian patterns and stress is a consequence of modern day society (103).

\section{IMPLICATIONS FOR THE USE OF PRO- AND PREBIOTICS}

There is still controversy about the effectiveness of probiotic and prebiotic treatment in food allergy (104). However, given the data that alteration of the gut microbiota influences mucosal immune responses in the gut indicates that treatment using

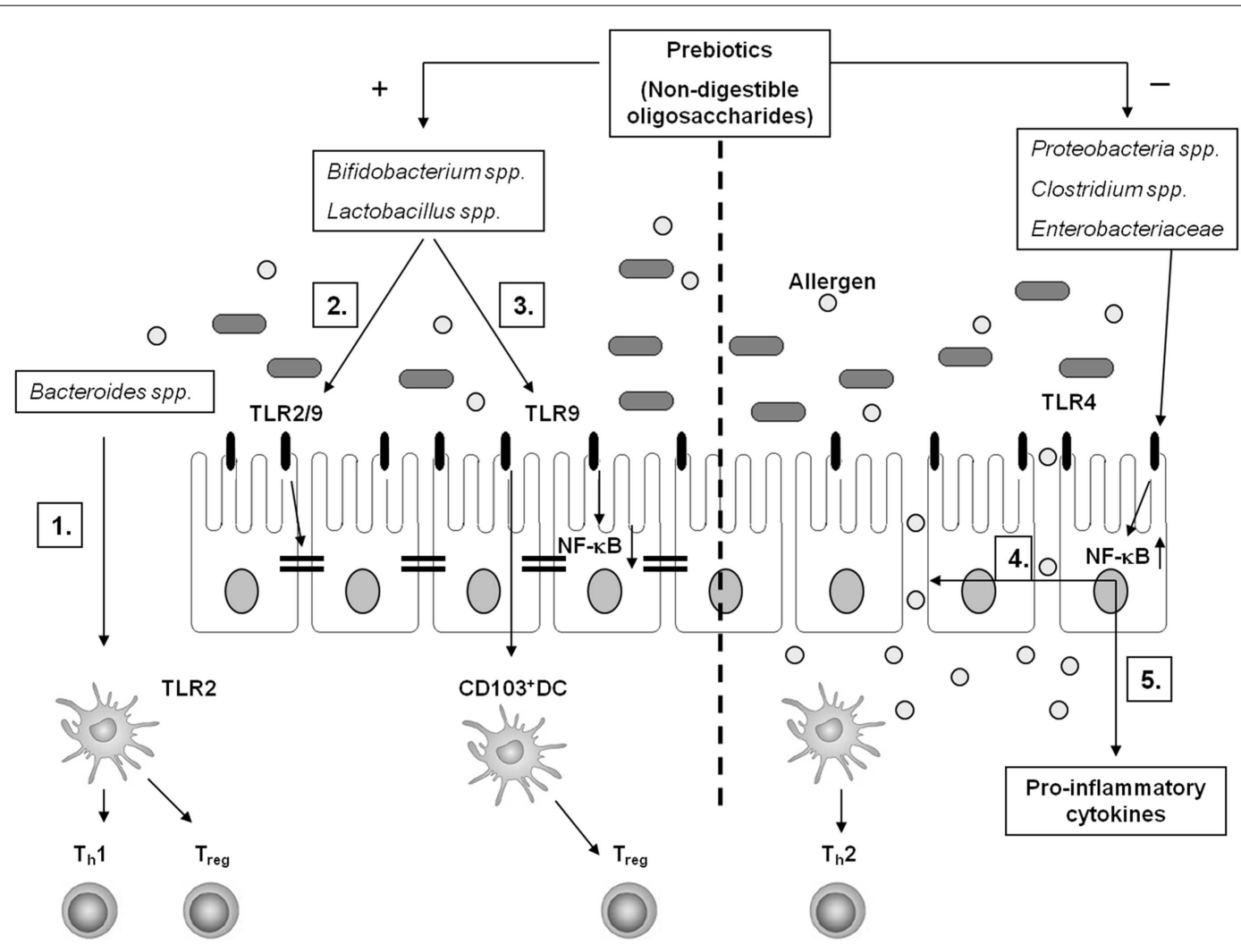

FIGURE 1 | Schematic overview of potential interactions between the gut microbiota and the intestinal mucosal immune system. A healthy gut microbiota composition is high in the frequency of Bacteroides spp., Lactobacillus spp., and Bifidobacterium spp. (1) In particular, Bacteroides fragilis supports $\mathrm{T}_{\mathrm{h}} 1$ and $\mathrm{T}_{\text {reg }}$ polarization in a TLR2-dependent manner through recognition of polysaccharide A by gut DC. Genomic DNA of Bifidobacterium spp. and Lactobacillus spp. - rich in unmethylated CpG motifs - potentially interact with TLR2 and/or TLR9 to enhance the intestinal epithelial barrier function (2) and to support $T_{\text {reg }}$ conversion via $\mathrm{CD}_{103^{+}} \mathrm{DC}$ (3). Furthermore, apical TLR9 activation by IEC suppresses
NF-kB activation (3). In food allergy, the microbiota composition shifts toward a higher frequency in Proteobacteria spp., Clostridium spp., and Enterobacteriaceae. This may favor TLR4 mediated barrier disruption facilitating allergen translocation in the gut mucosa (4) and pro-inflammatory cytokine production (5) in a NF-kB-dependent fashion, sustaining an allergic inflammation. Specific non-digestible oligosaccharides (prebiotics) support the growth of Bifidobacterium spp. and Lactobacillus spp. and suppresses the growth of Clostridium spp. and Enterobacteriaceae, which may contribute to induction of tolerance toward allergens in the intestines. 
specific probiotic bacterial strains as well as prebiotics may be useful in treatment for food allergy (Figure 1). Selection of the right bacterial strains appears key to the effect of treatment using probiotics. Especially, characterization of specific probiotics based on $\mathrm{CpG}$ rich motifs in the DNA may improve the selection of potential beneficial strains. Hence, studies aimed at the interaction between probiotic bacteria and epithelial expressed TLRs may be warranted. In addition, timing of treatment may play an essential factor in the effectiveness of treatment using pro- and prebiotics as expression of TLRs and immune cell functions appears to be regulated by the circadian clock. In conclusion, more studies are necessary focusing on interaction between the gut epithelium and gut bacteria, both in terms of selecting potential beneficial bacterial strains as well as appropriate timing of intervention.

\section{AUTHOR CONTRIBUTIONS}

Sander de Kivit wrote the manuscript; Mary C. Tobin, Christopher B. Forsyth carefully reviewed the manuscript; Ali Keshavarzian and Alan L. Landay reviewed the manuscript and provided overall supervision.

\section{ACKNOWLEDGMENT}

This work is financially supported by a generous gift from $\mathrm{Mr}$. and Mrs. Burridge.

\section{REFERENCES}

1. Linden SK, Sutton P, Karlsson NG, Korolik V, McGuckin MA. Mucins in the mucosal barrier to infection. Mucosal Immunol (2008) 1(3):183-97. doi: $10.1038 / \mathrm{mi} .2008 .5$

2. Salzman NH, Hung K, Haribhai D, Chu H, Karlsson-Sjöberg J, Amir E, et al. Enteric defensins are essential regulators of intestinal microbial ecology. Nat Immunol (2010) 11(1):76-83. doi:10.1038/ni.1825

3. Mowat AM. Anatomical basis of tolerance and immunity to intestinal antigens. Nat Rev Immunol (2003) 3(4):331-41. doi:10.1038/nri1057

4. Mabbott NA, Donaldson DS, Ohno H, Williams IR, Mahajan A. Microfold (M) cells: important immunosurveillance posts in the intestinal epithelium. Mucosal Immunol (2013) 6(4):666-77. doi:10.1038/mi.2013.30

5. Rescigno M, Urbano M, Valzasina B, Francolini M, Rotta G, Bonasio R, et al. Dendritic cells express tight junction proteins and penetrate gut epithelial monolayers to sample bacteria. Nat Immunol (2001) 2(4):361-7. doi:10.1038/ 86373

6. Niess JH, Brand S, Gu X, Landsman L, Jung S, McCormick BA, et al. CX3CR1mediated dendritic cell access to the intestinal lumen and bacterial clearance. Science (2005) 307(5707):254-8. doi:10.1126/science.1102901

7. Agace WW. Tissue-tropic effector T cells: generation and targeting opportunities. Nat Rev Immunol (2006) 6(9):682-92. doi:10.1038/nri1869

8. Butler M, Ng CY, van Heel DA, Lombardi G, Lechler R, Playford RJ, et al. Modulation of dendritic cell phenotype and function in an in vitro model of the intestinal epithelium. Eur J Immunol (2006) 36(4):864-74. doi:10.1002/eji. 200535497

9. Coombes JL, Siddiqui KR, Arancibia-Cárcamo CV, Hall J, Sun CM, Belkaid Y, et al. A functionally specialized population of mucosal CD103+ DCs induces Foxp3+ regulatory T cells via a TGF-beta and retinoic acid-dependent mechanism. J Exp Med (2007) 204(8):1757-64. doi:10.1084/jem.20070590

10. Sun CM, Hall JA, Blank RB, Bouladoux N, Oukka M, Mora JR, et al. Small intestine lamina propria dendritic cells promote de novo generation of Foxp3 T reg cells via retinoic acid. J Exp Med (2007) 204(8):1775-85. doi:10.1084/jem.20070602

11. Iliev ID, Spadoni I, Mileti E, Matteoli G, Sonzogni A, Sampietro GM, et al. Human intestinal epithelial cells promote the differentiation of tolerogenic dendritic cells. Gut (2009) 58(11):1481-9. doi:10.1136/gut.2008.175166

12. Spadoni I, Iliev ID, Rossi G, Rescigno M. Dendritic cells produce TSLP that limits the differentiation of Th17 cells, fosters Treg development, and protects against colitis. Mucosal Immunol (2012) 5(2):184-93. doi:10.1038/mi.2011.64
13. Johansson-Lindbom B, Svensson M, Pabst O, Palmqvist C, Marquez G, Förster $\mathrm{R}$, et al. Functional specialization of gut CD103+ dendritic cells in the regulation of tissue-selective T cell homing. J Exp Med (2005) 202(8):1063-73. doi:10.1084/jem.20051100

14. Adel-Patient K, Wavrin S, Bernard H, Meziti N, Ah-Leung S, Wal JM. Oral tolerance and Treg cells are induced in BALB/c mice after gavage with bovine beta-lactoglobulin. Allergy (2011) 66(10):1312-21. doi:10.1111/j.1398-9995. 2011.02653.x

15. Yamashita H, Takahashi K, Tanaka H, Nagai H, Inagaki N. Overcoming food allergy through acquired tolerance conferred by transfer of Tregs in a murine model. Allergy (2012) 67(2):201-9. doi:10.1111/j.1398-9995.2011. 02742.x

16. Shreffler WG, Castro RR, Kucuk ZY, Charlop-Powers Z, Grishina G, Yoo S, et al. The major glycoprotein allergen from Arachis hypogaea, Ara h 1, is a ligand of dendritic cell-specific ICAM-grabbing nonintegrin and acts as a Th2 adjuvant in vitro. J Immunol (2006) 177(6):3677-85.

17. Akdis CA, Akdis M. Mechanisms of allergen-specific immunotherapy. J Allergy Clin Immunol (2011) 127(1):18-27; quiz 8-9. doi:10.1016/j.jaci.2010.11.030

18. Lee J, Mo JH, Katakura K, Alkalay I, Rucker AN, Liu YT, et al. Maintenance of colonic homeostasis by distinctive apical TLR9 signalling in intestinal epithelial cells. Nat Cell Biol (2006) 8(12):1327-36. doi:10.1038/ncb1500

19. Ewaschuk JB, Backer JL, Churchill TA, Obermeier F, Krause DO, Madsen KL. Surface expression of Toll-like receptor 9 is upregulated on intestinal epithelial cells in response to pathogenic bacterial DNA. Infect Immun (2007) 75(5):2572-9. doi:10.1128/IAI.01662-06

20. Abreu MT, Vora P, Faure E, Thomas LS, Arnold ET, Arditi M. Decreased expression of Toll-like receptor-4 and MD-2 correlates with intestinal epithelial cell protection against dysregulated proinflammatory gene expression in response to bacterial lipopolysaccharide. J Immunol (2001) 167(3):1609-16.

21. Melmed G, Thomas LS, Lee N, Tesfay SY, Lukasek K, Michelsen KS, et al. Human intestinal epithelial cells are broadly unresponsive to Toll-like receptor 2-dependent bacterial ligands: implications for host-microbial interactions in the gut. J Immunol (2003) 170(3):1406-15.

22. Abreu MT, Arnold ET, Thomas LS, Gonsky R, Zhou Y, Hu B, et al. TLR4 and MD-2 expression is regulated by immune-mediated signals in human intestinal epithelial cells. J Biol Chem (2002) 277(23):20431-7. doi:10.1074/ jbc.M110333200

23. Singh JC, Cruickshank SM, Newton DJ, Wakenshaw L, Graham A, Lan J, et al. Toll-like receptor-mediated responses of primary intestinal epithelial cells during the development of colitis. Am J Physiol Gastrointest Liver Physiol (2005) 288(3):G514-24. doi:10.1152/ajpgi.00377.2004

24. Frolova L, Drastich P, Rossmann P, Klimesova K, Tlaskalova-Hogenova H. Expression of Toll-like receptor 2 (TLR2), TLR4, and CD14 in biopsy samples of patients with inflammatory bowel diseases: upregulated expression of TLR2 in terminal ileum of patients with ulcerative colitis. J Histochem Cytochem (2008) 56(3):267-74. doi:10.1369/jhc.7A7303.2007

25. de Kivit S, van Hoffen E, Korthagen N, Garssen J, Willemsen LE. Apical TLR ligation of intestinal epithelial cells drives a Th1-polarized regulatory or inflammatory type effector response in vitro. Immunobiology (2011) 216(4):518-27. doi:10.1016/j.imbio.2010.08.005

26. de Kivit S, Kraneveld AD, Knippels LM, van Kooyk Y, Garssen J, Willemsen LE. Intestinal epithelium-derived galectin- 9 is involved in the immunomodulating effects of nondigestible oligosaccharides. J Innate Immun (2013) 5(6):625-38. doi:10.1159/000350515

27. de Kivit S, Saeland E, Kraneveld AD, van de Kant HJ, Schouten B, van Esch BC, et al. Galectin- 9 induced by dietary synbiotics is involved in suppression of allergic symptoms in mice and humans. Allergy (2012) 67(3):343-52. doi:10.1111/j.1398-9995.2011.02771.x

28. Farache J, Koren I, Milo I, Gurevich I, Kim KW, Zigmond E, et al. Luminal bacteria recruit CD103+ dendritic cells into the intestinal epithelium to sample bacterial antigens for presentation. Immunity (2013) 38(3):581-95. doi:10.1016/j.immuni.2013.01.009

29. Iemoli E, Trabattoni D, Parisotto S, Borgonovo L, Toscano M, Rizzardini G, et al. Probiotics reduce gut microbial translocation and improve adult atopic dermatitis. J Clin Gastroenterol (2012) 46(Suppl):S33-40. doi:10.1097/MCG. 0b013e31826a8468

30. Cario E, Gerken G, Podolsky DK. Toll-like receptor 2 enhances ZO-1-associated intestinal epithelial barrier integrity via protein kinase C. Gastroenterology (2004) 127(1):224-38. doi:10.1053/j.gastro.2004.04.015 
31. Li X, Wang C, Nie J, Lv D, Wang T, Xu Y. Toll-like receptor 4 increases intestinal permeability through up-regulation of membrane PKC activity in alcoholic steatohepatitis. Alcohol (2013) 47(6):459-65. doi:10.1016/j.alcohol.2013. 05.004

32. Cario E, Rosenberg IM, Brandwein SL, Beck PL, Reinecker HC, Podolsky DK. Lipopolysaccharide activates distinct signaling pathways in intestinal epithelial cell lines expressing Toll-like receptors. J Immunol (2000) 164(2):966-72.

33. Sodhi C, Levy R, Gill R, Neal MD, Richardson W, Branca M, et al. DNA attenuates enterocyte Toll-like receptor 4-mediated intestinal mucosal injury after remote trauma. Am J Physiol Gastrointest Liver Physiol (2011) 300(5):G862-73. doi:10.1152/ajpgi.00373.2010

34. Chen ML, Ge Z, Fox JG, Schauer DB. Disruption of tight junctions and induction of proinflammatory cytokine responses in colonic epithelial cells by Campylobacter jejuni. Infect Immun (2006) 74(12):6581-9. doi:10.1128/IAI. 00958-06

35. O'Hara JR, Feener TD, Fischer CD, Buret AG. Campylobacter jejuni disrupts protective Toll-like receptor 9 signaling in colonic epithelial cells and increases the severity of dextran sulfate sodium-induced colitis in mice. Infect Immun (2012) 80(4):1563-71. doi:10.1128/IAI.06066-11

36. Breiteneder H, Radauer C. A classification of plant food allergens. JAllergy Clin Immunol (2004) 113(5):821-30. doi:10.1016/j.jaci.2004.01.779

37. Junker Y, Zeissig S, Kim SJ, Barisani D, Wieser H, Leffler DA, et al. Wheat amylase trypsin inhibitors drive intestinal inflammation via activation of toll-like receptor 4. J Exp Med (2012) 209(13):2395-408. doi:10.1084/jem.20102660

38. Ryan CA. Protease inhibitors in plants: genes for improving defenses against insects and pathogens. Annu Rev Phytopathol (1990) 28:425-49. doi:10.1146/ annurev.phyto.28.1.425

39. Cordain L. Cereal grains: humanity's double-edged sword. World Rev Nutr Diet (1999) 84:19-73. doi:10.1159/000059677

40. Sands DC, Morris CE, Dratz EA, Pilgeram AL. Elevating optimal human nutrition to a central goal of plant breeding and production of plant-based foods. Plant Sci (2009) 177(5):377-89. doi:10.1016/j.plantsci.2009.07.011

41. Herre J, Grönlund H, Brooks H, Hopkins L, Waggoner L, Murton B, et al. Allergens as immunomodulatory proteins: the cat dander protein Fel d 1 enhances TLR activation by lipid ligands. J Immunol (2013) 191(4):1529-35. doi:10.4049/jimmunol.1300284

42. Zhong Y, Huang J, Tang W, Chen B, Cai W. Effects of probiotics, probiotic DNA and the CpG oligodeoxynucleotides on ovalbumin-sensitized BrownNorway rats via TLR9/NF-кB pathway. FEMS Immunol Med Microbiol (2012) 66(1):71-82. doi:10.1111/j.1574-695X.2012.00991.x

43. Artis D, Grencis RK. The intestinal epithelium: sensors to effectors in nematode infection. Mucosal Immunol (2008) 1(4):252-64. doi:10.1038/mi.2008.21

44. Romagnani S. The increased prevalence of allergy and the hygiene hypothesis: missing immune deviation, reduced immune suppression, or both? Immunology (2004) 112(3):352-63. doi:10.1111/j.1365-2567.2004.01925.x

45. Noval Rivas M, Burton OT, Wise P, Zhang YQ, Hobson SA, Garcia Lloret M, et al. A microbiota signature associated with experimental food allergy promotes allergic sensitization and anaphylaxis. J Allergy Clin Immunol (2013) 131(1):201-12. doi:10.1016/j.jaci.2012.10.026

46. Rodriguez B, Prioult G, Hacini-Rachinel F, Moine D, Bruttin A, Ngom-Bru $\mathrm{C}$, et al. Infant gut microbiota is protective against cow's milk allergy in mice despite immature ileal T-cell response. FEMS Microbiol Ecol (2012) 79(1):192-202. doi:10.1111/j.1574-6941.2011.01207.x

47. Jeon SG, Kayama H, Ueda Y, Takahashi T, Asahara T, Tsuji H, et al. Probiotic Bifidobacterium breve induces IL-10-producing $\operatorname{Tr} 1$ cells in the colon. PLoS Pathog (2012) 8(5):e1002714. doi:10.1371/journal.ppat.1002714

48. Mazmanian SK, Round JL, Kasper DL. A microbial symbiosis factor prevents intestinal inflammatory disease. Nature (2008) 453(7195):620-5. doi:10.1038/ nature 07008

49. Round JL, Mazmanian SK. Inducible Foxp3+ regulatory T-cell development by a commensal bacterium of the intestinal microbiota. Proc Natl Acad Sci U S A (2010) 107(27):12204-9. doi:10.1073/pnas.0909122107

50. Penders J, Stobberingh EE, van den Brandt PA, Thijs C. The role of the intestinal microbiota in the development of atopic disorders. Allergy (2007) 62(11):1223-36. doi:10.1111/j.1398-9995.2007.01462.x

51. Loh G, Blaut M. Role of commensal gut bacteria in inflammatory bowel diseases. Gut Microbes (2012) 3(6):544-55. doi:10.4161/gmic.22156

52. Bjorksten B, Sepp E, Julge K, Voor T, Mikelsaar M. Allergy development and the intestinal microflora during the first year of life. J Allergy Clin Immunol (2001) 108(4):516-20. doi:10.1067/mai.2001.118130
53. Murray CS, Tannock GW, Simon MA, Harmsen HJ, Welling GW, Custovic A, et al. Fecal microbiota in sensitized wheezy and non-sensitized non-wheezy children: a nested case-control study. Clin Exp Allergy (2005) 35(6):741-5. doi:10.1111/j.1365-2222.2005.02259.x

54. Johansson MA, Saghafian-Hedengren S, Haileselassie Y, Roos S, TroyeBlomberg M, Nilsson C, et al. Early-life gut bacteria associate with IL-4-, IL-10- and IFN-gamma production at two years of age. PLoS One (2012) 7(11):e49315. doi:10.1371/journal.pone.0049315

55. Ismail IH, Oppedisano F, Joseph SJ, Boyle RJ, Robins-Browne RM, Tang ML. Prenatal administration of Lactobacillus rhamnosus has no effect on the diversity of the early infant gut microbiota. Pediatr Allergy Immunol (2012) 23(3):255-8. doi:10.1111/j.1399-3038.2011.01239.x

56. Hayashi A, Sato T, Kamada N, Mikami Y, Matsuoka K, Hisamatsu T, et al. A single strain of Clostridium butyricum induces intestinal IL-10-producing macrophages to suppress acute experimental colitis in mice. Cell Host Microbe (2013) 13(6):711-22. doi:10.1016/j.chom.2013.05.013

57. Isono A, Katsuno T, Sato T, Nakagawa T, Kato Y, Sato N, et al. Clostridium butyricum TO-A culture supernatant downregulates TLR4 in human colonic epithelial cells. Dig Dis Sci (2007) 52(11):2963-71. doi:10.1007/s10620-0069593-3

58. He F, Morita H, Hashimoto H, Hosoda M, Kurisaki J, Ouwehand AC, et al. Intestinal Bifidobacterium species induce varying cytokine production. JAllergy Clin Immunol (2002) 109(6):1035-6. doi:10.1067/mai.2002.124894

59. Prescott SL, Noakes P, Chow BW, Breckler L, Thornton CA, Hollams EM, et al. Presymptomatic differences in Toll-like receptor function in infants who have allergy. J Allergy Clin Immunol (2008) 122(2):391-9; 9.e1-5. doi:10.1016/j.jaci. 2008.04.042

60. Haller D, Bode C, Hammes WP, Pfeifer AM, Schiffrin EJ, Blum S. Non-pathogenic bacteria elicit a differential cytokine response by intestinal epithelial cell/leucocyte co-cultures. Gut (2000) 47(1):79-87. doi:10.1136/gut. 47.1.79

61. van Hoffen E, Korthagen NM, de Kivit S, Schouten B, Bardoel B, Duivelshof A, et al. Exposure of intestinal epithelial cells to UV-killed Lactobacillus GG but not Bifidobacterium breve enhances the effector immune response in vitro. Int Arch Allergy Immunol (2010) 152(2):159-68. doi:10.1159/000265537

62. Vizoso Pinto MG, Rodriguez Gomez M, Seifert S, Watzl B, Holzapfel WH, Franz CM. Lactobacilli stimulate the innate immune response and modulate the TLR expression of HT29 intestinal epithelial cells in vitro. Int J Food Microbiol (2009) 133(1-2):86-93. doi:10.1016/j.ijfoodmicro.2009.05.013

63. Kingma SD, Li N, Sun F, Valladares RB, Neu J, Lorca GL. Lactobacillus johnsonii N6.2 stimulates the innate immune response through Toll-like receptor 9 in Caco-2 cells and increases intestinal crypt Paneth cell number in biobreeding diabetes-prone rats. J Nutr (2011) 141(6):1023-8. doi:10.3945/jn.110.135517

64. Eun CS, Kim YS, Han DS, Choi JH, Lee AR, Park YK. Lactobacillus casei prevents impaired barrier function in intestinal epithelial cells. APMIS (2011) 119(1):49-56. doi:10.1111/j.1600-0463.2010.02691.x

65. Furrie E, Macfarlane S, Thomson G, Macfarlane GT, Microbiology \& Gut Biology Group, Tayside Tissue \& Tumour Bank. Toll-like receptors-2, -3 and -4 expression patterns on human colon and their regulation by mucosalassociated bacteria. Immunology (2005) 115(4):565-74. doi:10.1111/j.13652567.2005.02200.x

66. Ghadimi D, Vrese M, Heller KJ, Schrezenmeir J. Effect of natural commensalorigin DNA on toll-like receptor 9 (TLR9) signaling cascade, chemokine IL-8 expression, and barrier integritiy of polarized intestinal epithelial cells. Inflamm Bowel Dis (2010) 16(3):410-27. doi:10.1002/ibd.21057

67. Lyons A, O'Mahony D, O’Brien F, MacSharry J, Sheil B, Ceddia M, et al. Bacterial strain-specific induction of Foxp3+ T regulatory cells is protective in murine allergy models. Clin Exp Allergy (2010) 40(5):811-9. doi:10.1111/j.1365-2222. 2009.03437.x

68. Smelt MJ, de Haan BJ, Bron PA, van Swam I, Meijerink M, Wells JM, et al. L. plantarum, L. salivarius, and L. lactis attenuate Th2 responses and increase Treg frequencies in healthy mice in a strain dependent manner. PLoS One (2012) 7(10):e47244. doi:10.1371/journal.pone.0047244

69. von der Weid T, Bulliard C, Schiffrin EJ. Induction by a lactic acid bacterium of a population of CD4(+) T cells with low proliferative capacity that produce transforming growth factor beta and interleukin-10. Clin Diagn Lab Immunol (2001) 8(4):695-701.

70. Smits HH, Engering A, van der Kleij D, de Jong EC, Schipper K, van Capel TM, et al. Selective probiotic bacteria induce IL-10-producing regulatory $\mathrm{T}$ cells in vitro by modulating dendritic cell function through dendritic cell-specific 
intercellular adhesion molecule 3-grabbing nonintegrin. JAllergy Clin Immunol (2005) 115(6):1260-7. doi:10.1016/j.jaci.2005.03.036

71. Lammers KM, Brigidi P, Vitali B, Gionchetti P, Rizzello F, Caramelli E, et al. Immunomodulatory effects of probiotic bacteria DNA: IL-1 and IL-10 response in human peripheral blood mononuclear cells. FEMS Immunol Med Microbiol (2003) 38(2):165-72. doi:10.1016/S0928-8244(03)00144-5

72. Zhang LL, Chen X, Zheng PY, Luo Y, Lu GF, Liu ZQ, et al. Oral Bifidobacterium modulates intestinal immune inflammation in mice with food allergy. J Gastroenterol Hepatol (2010) 25(5):928-34. doi:10.1111/j.1440-1746.2009. 06193.x

73. Bouladoux N, Hall JA, Grainger JR, dos Santos LM, Kann MG, Nagarajan V, et al. Regulatory role of suppressive motifs from commensal DNA. Mucosal Immunol (2012) 5(6):623-34. doi:10.1038/mi.2012.36

74. Akhtar M, Watson JL, Nazli A, McKay DM. Bacterial DNA evokes epithelial IL-8 production by a MAPK-dependent, NF-kappaB-independent pathway. FASEB $J$ (2003) 17(10):1319-21.

75. Campeau JL, Salim SY, Albert EJ, Hotte N, Madsen KL. Intestinal epithelial cells modulate antigen-presenting cell responses to bacterial DNA. Infect Immun (2012) 80(8):2632-44. doi:10.1128/IAI.00288-12

76. Haarman M, Knol J. Quantitative real-time PCR assays to identify and quantify fecal Bifidobacterium species in infants receiving a prebiotic infant formula. Appl Environ Microbiol (2005) 71(5):2318-24. doi:10.1128/AEM.71.5. 2318-2324.2005

77. Boehm G, Stahl B, Jelinek J, Knol J, Miniello V, Moro GE. Prebiotic carbohydrates in human milk and formulas. Acta Paediatr Suppl (2005) 94(449):18-21. doi:10.1111/j.1651-2227.2005.tb02149.x

78. Schouten B, van Esch BC, Hofman GA, Boon L, Knippels LM, Willemsen LE, et al. Oligosaccharide-induced whey-specific CD25(+) regulatory T-cells are involved in the suppression of cow milk allergy in mice. J Nutr (2010) 140(4):835-41. doi:10.3945/jn.109.116061

79. Arslanoglu S, Moro GE, Schmitt J, Tandoi L, Rizzardi S, Boehm G. Early dietary intervention with a mixture of prebiotic oligosaccharides reduces the incidence of allergic manifestations and infections during the first two years of life. J Nutr (2008) 138(6):1091-5.

80. van Hoffen E, Ruiter B, Faber J, M'Rabet L, Knol EF, Stahl B, et al. A specific mixture of short-chain galacto-oligosaccharides and long-chain fructooligosaccharides induces a beneficial immunoglobulin profile in infants at high risk for allergy. Allergy (2009) 64(3):484-7. doi:10.1111/j.1398-9995.2008. 01765.x

81. Schouten B, van Esch BC, Hofman GA, van Doorn SA, Knol J, Nauta AJ, et al. Cow milk allergy symptoms are reduced in mice fed dietary synbiotics during oral sensitization with whey. J Nutr (2009) 139(7):1398-403. doi:10.3945/jn.109.108514

82. van der Aa LB, Heymans HS, van Aalderen WM, Sillevis Smitt JH, Knol J, Ben Amor K, et al. Effect of a new synbiotic mixture on atopic dermatitis in infants: a randomized-controlled trial. Clin Exp Allergy (2010) 40(5):795-804. doi:10.1111/j.1365-2222.2010.03465.x

83. Koleva PT, Valcheva RS, Sun X, Ganzle MG, Dieleman LA. Inulin and fructooligosaccharides have divergent effects on colitis and commensal microbiota in HLA-B27 transgenic rats. Br J Nutr (2012) 108(9):1633-43. doi:10.1017/ S0007114511007203

84. Karczewski J, Troost FJ, Konings I, Dekker J, Kleerebezem M, Brummer RJ, et al. Regulation of human epithelial tight junction proteins by Lactobacillus plantarum in vivo and protective effects on the epithelial barrier. Am J Physiol Gastrointest Liver Physiol (2010) 298(6):G851-9. doi:10.1152/ajpgi.00327.2009

85. Ewaschuk JB, Diaz H, Meddings L, Diederichs B, Dmytrash A, Backer J, et al. Secreted bioactive factors from Bifidobacterium infantis enhance epithelial cell barrier function. Am J Physiol Gastrointest Liver Physiol (2008) 295(5):G1025-34. doi:10.1152/ajpgi.90227.2008

86. Silver AC, Arjona A, Walker WE, Fikrig E. The circadian clock controls tolllike receptor 9-mediated innate and adaptive immunity. Immunity (2012) 36(2):251-61. doi:10.1016/j.immuni.2011

87. Froy O, Chapnik N. Circadian oscillation of innate immunity components in mouse small intestine. Mol Immunol (2007) 44(8):1954-60. doi:10.1016/j. molimm.2006.09.026

88. Mukherji A, Kobiita A, Ye T, Chambon P. Homeostasis in intestinal epithelium is orchestrated by the circadian clock and microbiota cues transduced by TLRs. Cell (2013) 153(4):812-27. doi:10.1016/j.cell.2013.04.020
89. Bollinger T, Leutz A, Leliavski A, Skrum L, Kovac J, Bonacina L, et al. Circadian clocks in mouse and human CD4+ T cells. PLoS One (2011) 6(12):e29801. doi:10.1371/journal.pone.0029801

90. Bollinger T, Bollinger A, Naujoks J, Lange T, Solbach W. The influence of regulatory T cells and diurnal hormone rhythms on Thelper cell activity. Immunology (2010) 131(4):488-500. doi:10.1111/j.1365-2567.2010.03320.x

91. Keller M, Mazuch J, Abraham U, Eom GD, Herzog ED, Volk HD, et al. A circadian clock in macrophages controls inflammatory immune responses. Proc Natl Acad Sci U S A (2009) 106(50):21407-12. doi:10.1073/pnas.0906361106

92. Fortier EE, Rooney J, Dardente H, Hardy MP, Labrecque N, Cermakian N. Circadian variation of the response of T cells to antigen. J Immunol (2011) 187(12):6291-300. doi:10.4049/jimmunol.1004030

93. Kirsch S, Thijssen S, Alarcon Salvador S, Heine GH, van Bentum K, Fliser D, et al. T-cell numbers and antigen-specific T-cell function follow different circadian rhythms. J Clin Immunol (2012) 32(6):1381-9. doi:10.1007/s10875-0129730-z

94. Bollinger T, Bollinger A, Skrum L, Dimitrov S, Lange T, Solbach W. Sleepdependent activity of T cells and regulatory T cells. Clin Exp Immunol (2009) 155(2):231-8. doi:10.1111/j.1365-2249.2008.03822.x

95. Prendergast BJ, Cable EJ, Patel PN, Pyter LM, Onishi KG, Stevenson TJ, et al. Impaired leukocyte trafficking and skin inflammatory responses in hamsters lacking a functional circadian system. Brain Behav Immun (2013) 32:94-104. doi:10.1016/j.bbi.2013.02.007

96. Mazzoccoli G, De Cata A, Greco A, Carughi S, Giuliani F, Tarquini R. Circadian rhythmicity of lymphocyte subpopulations and relationship with neuroendocrine system. J Biol Regul Homeost Agents (2010) 24(3):341-50.

97. Cernysiov V, Gerasimcik N, Mauricas M, Girkontaite I. Regulation of T-cellindependent and T-cell-dependent antibody production by circadian rhythm and melatonin. Int Immunol (2010) 22(1):25-34. doi:10.1093/intimm/dxp109

98. Keith C, Voigt RM, Forsyth CB, Shaikh M, Cavanaugh K, Tang Y, et al. Disruption of the circadian clock in mice increases intestinal permeability and promotes alcohol-induced hepatic pathology and inflammation. PLoS One (2013) 8(6):e67102. doi:10.1371/journal.pone.0067102

99. Martin RJ. Location of airway inflammation in asthma and the relationship to circadian change in lung function. Chronobiol Int (1999) 16(5):623-30. doi:10.3109/07420529908998731

100. Majde JA, Krueger JM. Links between the innate immune system and sleep. J Allergy Clin Immunol (2005) 116(6):1188-98. doi:10.1016/j.jaci.2005.08.005

101. Baumann A, Gönnenwein S, Bischoff SC, Sherman H, Chapnik N, Froy O, et al. The circadian clock is functional in eosinophils and mast cells. Immunology (2013) 140(4):465-74. doi:10.1111/imm.12157

102. Nakamura Y, Nakano N, Ishimaru K, Hara M, Ikegami T, Tahara Y, et al. Circadian regulation of allergic reactions by the mast cell clock in mice. J Allergy Clin Immunol (2014) 133(2):568-75.e12. doi:10.1016/j.jaci.2013.07.040

103. Ball TM, Anderson D, Minto J, Halonen M. Cortisol circadian rhythms and stress responses in infants at risk of allergic disease. J Allergy Clin Immunol (2006) 117(2):306-11. doi:10.1016/j.jaci.2005.11.009

104. Nermes M, Salminen S, Isolauri E. Is there a role for probiotics in the prevention or treatment of food allergy? Curr Allergy Asthma Rep (2013) 13(6):622-30. doi:10.1007/s11882-013-0381-9

Conflict of Interest Statement: The authors declare that the research was conducted in the absence of any commercial or financial relationships that could be construed as a potential conflict of interest.

Received: 02 December 2013; accepted: 03 February 2014; published online: 18 February 2014.

Citation: de Kivit S, Tobin MC, Forsyth CB, Keshavarzian A and Landay AL (2014) Regulation of intestinal immune responses through TLR activation: implications for pro- and prebiotics. Front. Immunol. 5:60. doi: 10.3389/fimmu.2014.00060

This article was submitted to Immunological Tolerance, a section of the journal Frontiers in Immunology.

Copyright $\odot 2014$ de Kivit, Tobin, Forsyth, Keshavarzian and Landay. This is an openaccess article distributed under the terms of the Creative Commons Attribution License (CC BY). The use, distribution or reproduction in other forums is permitted, provided the original author(s) or licensor are credited and that the original publication in this journal is cited, in accordance with accepted academic practice. No use, distribution or reproduction is permitted which does not comply with these terms. 